\title{
Diagnostic Accuracy of Digital Radiography and Novel Diagnostic Tools versus Visual ICDAS Criteria: A Systematic Review
}

\author{
Shereen Hafez Ibrahim ${ }^{1 *}$, Reham Nabil ${ }^{2}$, Peter Edward ${ }^{2}$ \\ ${ }^{1}$ Assistant professor of Conservative Dentistry, Faculty of Dentistry, Cairo University, Cairo, Egypt \\ ${ }^{2}$ Assistant lecturer of Conservative Dentistry, Faculty of Dentistry, Cairo University, Cairo, Egypt
}

\section{ABSTRACT}

Purpose: To evaluate the diagnostic accuracy of digital radiography and other novel diagnostic tools compared to visual ICDAS criteria.

Materials and Methods: Two reviewers performed a literature search up to May 2020 in three databases: PubMed, Google Scholar, and Cochrane Library. Only in-vivo studies that evaluated the diagnostic accuracy of digital radiography, Diagnodent, Vistaproof, Soprolife, and ICDAS criteria were included.

Results: A total of 27 in vivo studies were included in the systematic review. Studies included suggested that digital dental radiography proved to be a reliable tool in detecting initial carious lesions/ especially proximal lesions. The Diagnodent device was proved to be an efficient adjunct to other detection methods, especially in the case of non-experienced clinicians. For VistaCam/VistaProof assessment, it was found that in some articles, VistaCam proved high accuracy in detecting early carious lesions with moderate to strong correlation in comparison to results obtained by visual and tactile methods ICDAS criteria. ICDAS criteria were considered to be sufficient alone in detecting occlusal caries.

Conclusions: The in vivo evidence suggested that None of the diagnostic methods alone are sufficient for diagnosis of dental caries.

Keywords: Diagnostic Accuracy; Digital Radiography; Novel Diagnostic Tools; ICDAS Visual Criteria; Systematic Review

\section{INTRODUCTION}

The diagnosis of dental caries is always a challenge since its patterns and prevalence have significantly changed in the last few years. The difficulty in diagnosing dental caries depends not only on the morphological changes of lesions and their rate of progression but also on the lack of a precise methodology to efficiently diagnose both the disease and the integrity of the dental structure (specificity) [1].

Conventional examination for caries detection is primarily done using visual inspection, tactile sensation, and radiographs. While these methods give satisfactory results in the detection of cavitated lesions,
Vol No: 05, Issue: 01

Received Date: March 10, 2021

Published Date: April 13, 2021

\section{*Corresponding Author}

\section{Shereen Hafez Ibrahim}

Associate Professor of Conservative Dentistry, Department of Conservative Dentistry, Faculty of Dentistry, Cairo University, 11 EL-Saraya St. Manial, Cairo, Postal Code: 11553, Egypt, Tel:+201099296591

E-mail: shereen.hafez@dentistry.cu.edu.eg

Citation: Ibrahim SH, Nabil R, Edward P. (2021). Diagnostic Accuracy of Digital Radiography and Novel Diagnostic Tools versus Visual ICDAS Criteria: A Systematic Review. Mathews J Dentistry. 5(1):27.

Copyright: Ibrahim SH, et al. (C) (2021). This is an open-access article distributed under the terms of the Creative Commons Attribution License, which permits unrestricted use, distribution, and reproduction in any medium, provided the original author and source are credited. 
they are usually inadequate for the detection of initial lesions. Because of these deficiencies, new detection methods have been developed to aid better diagnosis [2].

To date, there are two main techniques aimed at helping clinicians in detecting caries represented by visual examination and by light-based caries diagnostic tools as fiber-optic transillumination (FOTI), DIAGNODent tool (KaVo), and SOPROLIFE. Visual diagnosing of caries has progressed by establishing the international caries detection and assessment system (ICDAS). ICDAS-II, the second version, was improved and provided a standardized system to enable clinicians to diagnose and detect the first visual change in enamel, leading to better information for clinical management [3].

There are various fluorescence-based methods, of which the most commonly studied are KAVO $®$ DIAGNOdent and VistaProof by Durr Dental $\AA$, which may be used as complementary diagnostic tools in order to avoid the occurrence of false-positive and false-negative findings. VistaProof an intraoral camera which emits a $405 \mathrm{~nm}$ light wavelength and takes images that are computer-processed; the resulting mapping of the lesion is produced according to its depth $[4,5]$.

The aim of this systematic review is to evaluate the diagnostic accuracy of digital radiography and other novel diagnostic tools in comparison to visual ICDAS criteria.

\section{MATERIALS AND METHODS}

This systematic review was reported according to the guidelines of the PRISMA statement. The protocol was registered in the PROSPERO international database for systematic reviews (CRD-183388). The research question was: What is the diagnostic accuracy of digital radiography and other novel diagnostic tools in comparison to visual ICDAS criteria?

A detailed database search was conducted using Medical Subject Heading terms [Table 1] in PubMed, Cochrane Library, and google scholar. The search words included digital radiograph, dental digital radiograph, Diagnodent, laser fluorescence devices, Vistaproof/Vistacam, Soprolife, initial caries, and microcavities. The search was restricted to articles published in the English language with a time period limit from 2000 to 2020 .

\section{INCLUSION CRITERIA}

- In vivo studies on caries detection methods

- Studies on diagnostic methods reporting diagnostic accuracy, i.e., sensitivity, specificity, and receiver operating characteristic curves

- Studies on primary/permanent teeth validated with reference/gold standard

- Studies published in the English language only from 2000 to April 2020.

\section{EXCLUSION CRITERIA}

- In vitro studies

- Studies with an incomplete description of the sample size or outcome

- Studies reporting accuracy in laboratory work exclusively

- Animal studies, review articles, letters to the editor and conference abstracts.

\begin{tabular}{|c|c|c|c|c|}
\hline & Population & Intervention & Comparison & Outcome/effect \\
\hline PICO & $\begin{array}{l}\text { Children/adult, } \\
\text { Occlusal/proximal } \\
\text { surfaces }\end{array}$ & $\begin{array}{l}\text { Digital radiography, Diagnodent, } \\
\text { Vistaprrof, Soprolife }\end{array}$ & $\begin{array}{l}\text { Visual ICDAS diagnostic } \\
\text { criteria }\end{array}$ & $\begin{array}{l}\text { Diagnostic accuracy in } \\
\text { caries detection }\end{array}$ \\
\hline Mesh terms & Initial caries & $\begin{array}{l}\text { Dental digital radiography, } \\
\text { Diagnodent device, Soprolife, and } \\
\text { Vistaproof camera }\end{array}$ & Visual ICDAS criteria & $\begin{array}{l}\text { Sensitivity and specificity, } \\
\text { dental caries }\end{array}$ \\
\hline $\begin{array}{l}\text { Alternate } \\
\text { search } \\
\text { terms }\end{array}$ & Microcavities & $\begin{array}{l}\text { Direct digital radiography, laser } \\
\text { fluorescence devices, intra-oral } \\
\text { cameras }\end{array}$ & $\begin{array}{l}\text { ICDAS \& modified ICDAS } \\
\text { visual diagnostic criteria }\end{array}$ & $\begin{array}{l}\text { Caries, initial caries } \\
\text { detection, lesion } \\
\text { monitoring }\end{array}$ \\
\hline
\end{tabular}

Table 1: Medical subject heading terms and alternate terms enclosed in the search strategy. 


\section{TYPE OF PARTICIPANTS}

All studies on human beings were included, regardless of age.

\section{TYPES OF STUDY}

All clinical trials on human beings and Occlusal/proximal surfaces were included. The English language was chosen.

\section{TYPE OF OUTCOME}

The main outcome was the absence or presence of dental caries using the following methods:

"Histological examination, the opening of cavities, or clinical examination based on ICDAS scores utilized in studies".

\section{REVIEW METHODS}

All reports yielded by the search were printed out and analyzed by two reviewers on the basis of title, keywords, and abstract to check if the study was likely relevant. A full report of all relevant papers was obtained, and also if a paper could not be classified.

The reviewers were not blinded to authors, journals, date of publication, financial support, or results. The inclusion criteria were applied, and the data assessed and extracted by two reviewers.

\section{RESULTS}

\section{For Digital Radiography}

The search strategies yielded eleven reports from the search database. All were published in the English language between 2008 and 2020. Three of these met the selection criteria after reading the full articles. Of the eight reports excluded, three were literature reviews, and the remaining, one systematic review and four were in vitro investigations.

Therefore, three studies were selected for analysis of the methodology and data reliability (Table 2).

\section{For Diagnodent}

The search strategies yielded fifteen reports from the search database. All were published in the English language between 2004 and 2020. Eight of these met the selection criteria after reading the full articles. Of the seven reports excluded, three were systematic reviews, and the remaining, and five were laboratory investigations.

Therefore, eight studies were selected for analysis of the methodology and data reliability (Table 3).

\section{For ICDAS Criteria}

The search strategies yielded eight reports from the search database. All were published in the English language between 2010 and 2020. Four of these met the inclusion criteria after reading the full articles. Of the four reports excluded, one was a systematic review, one literature review, and two were in vitro investigations.

Therefore, three studies were selected for analysis of the methodology and data reliability (Table 4).

\section{For Vista Cam/Vista Proof}

Following the search strategy, 17 articles were found in the search database. They were published between 2011 and 2020. Seven articles met the inclusion criteria after reading the full text, and the excluded ten articles included two literature reviews, 2 case reports, and five in-vitro studies, and one published in the Spanish language (Table 5).

\section{For Soprolife Camera}

Searching the databases according to the search strategy yielded ten articles that were found published between 2014 and 2019. Six articles met the selection criteria after reading the full articles. The excluded four articles included two systematic reviews, one case report, and one in-vitro study (Table 6). 


\begin{tabular}{|c|c|c|c|c|}
\hline Author/Year & Subjects & Methodology & Results & Conclusion \\
\hline $\begin{array}{l}\text { Sahu RK (2020) } \\
\text { [6] }\end{array}$ & $\begin{array}{l}\text { Occlusal surface for } \\
\text { fifty teeth of randomly } \\
\text { selected patients }\end{array}$ & $\begin{array}{l}\text { 1.Direct digital radiography } \\
\text { (DDR)-CMOS } \\
\text { 2. Four types of filtered } \\
\text { images }\end{array}$ & $\begin{array}{l}\text { Agreement statistics for intra and inter-evaluator comparisons were } \\
\text { maximum for the DDR-CMOS mode with a kappa coefficient of } 0.4108 \\
(95 \% \text { CI: } 0.1124-0.7091) \text {. This was followed by the Negative mode } \\
\text { with a coefficient of } 0.3065 \text {. }\end{array}$ & $\begin{array}{l}\text { DDR-CMOS and negative images were found to } \\
\text { be more useful in diagnosing occlusal caries. }\end{array}$ \\
\hline $\begin{array}{l}\text { Maria Melo } \\
\text { (2019) [7] }\end{array}$ & $\begin{array}{l}\text { Proximal caries of } \\
138 \text { posterior teeth } \\
(76 \text { molars and } 62 \\
\text { premolars) }\end{array}$ & $\begin{array}{l}\text { 1.Near-Infrared Light- } \\
\text { Transillumination (NILT) } \\
\text { 2.Direct digital-radiography } \\
\text { (DDR) } \\
\text { 3.Combination Opening Of } \\
\text { the approximal surface was } \\
\text { the gold standard }\end{array}$ & $\begin{array}{l}\text { Sensitivities of overall/D3/D4 were } 98.0 / 95.7 / 100.0 \text { (NILT) and } \\
100 / 100 / 100 \text { (DDR), respectively. Correlations with gold-standard } \\
\text { were } 0.92 \text { (NILT) and } 0.42 \text { (DDR), respectively. } \\
\text { The correlation increased to } 0.97(\mathrm{p}=0.045 \text { ) on combining NILT and } \\
\text { DDR. }\end{array}$ & $\begin{array}{l}\text { The combination of NILT and DDR represents } \\
\text { an increase in the diagnosis of approximal } \\
\text { lesions. The proposed diagnostic protocol } \\
\text { comprises visual examination, followed by } \\
\text { NILT and DDR only if the former technique } \\
\text { detects approximal caries. }\end{array}$ \\
\hline $\begin{array}{l}\text { Basem M. } \\
\text { Abuzenada } \\
\text { (2019) [8] }\end{array}$ & $\begin{array}{l}152 \text { bitewing } \\
\text { radiographs }\end{array}$ & $\begin{array}{l}\text { Bitewing digital } \\
\text { radiography }\end{array}$ & $\begin{array}{l}\text { The Kappa values for interobserver agreements were } 0.47 \text { and } 0.44 \text { in } \\
\text { the first and second observations, while for intraobserver agreements, } \\
\text { these values were } 0.61 \text { and } 0.69 \text { for the operative dentist and oral } \\
\text { radiologist, respectively }\end{array}$ & $\begin{array}{l}\text { The digital bitewing radiography resulted in } \\
\text { no variation in both the agreements, and it } \\
\text { was useful with respect to the reliability of the } \\
\text { diagnosis of interproximal caries. }\end{array}$ \\
\hline
\end{tabular}

Table 2: Selected studies about digital radiography. 


\begin{tabular}{|c|c|c|c|c|}
\hline Author/Year & Subjects & Methodology & Results & Conclusion \\
\hline $\begin{array}{l}\text { Castilho LS } \\
\text { (2016) [9] }\end{array}$ & $\begin{array}{l}\text { occlusal caries of } \\
43 \text { non-impacted } \\
\text { permanent third } \\
\text { molars; }\end{array}$ & $\begin{array}{l}\text { 1.DIAGNOdent laser fluorescence } \\
\text { 2.International Caries Detection } \\
\text { and Assessment System (ICDAS) } \\
\text { The gold standard is histological } \\
\text { examination }\end{array}$ & $\begin{array}{l}\text { The correlations with the histological reference were weak for } \\
\text { DIAGNOdent } \\
\text { (rs }=0.369 \text { ) and moderate for ICDAS ( } \mathrm{rs}=0.515 \text { ). The areas } \\
\text { under the (ROC) curve at D1, D2, and D3 were } 0.60,0.69 \text {, } \\
\text { and } 0.91 \text {, respectively, for ICDAS and } 0.55,0.65 \text {, and } 0.92 \text {, } \\
\text { respectively, for DIAGNOdent }\end{array}$ & $\begin{array}{l}\text { ICDAS and DIAGNOdent proved to be reproducible } \\
\text { methods with similar performance in the } \\
\text { detection of occlusal carious lesions in dentine. } \\
\text { The ability of DIAGNOdent to detect initial enamel } \\
\text { lesions was higher than that of ICDAS, but with low } \\
\text { specificity. The usefulness of DIAGNOdent as an } \\
\text { adjunct method for assessment of initial occlusal } \\
\text { caries in permanent molars is questionable. }\end{array}$ \\
\hline $\begin{array}{l}\text { Chaza Kouchaji } \\
\text { (2012) [4] }\end{array}$ & $\begin{array}{l}\text { occlusal caries of } 156 \\
\text { permanent molar } \\
\text { teeth in } 40 \text { children }\end{array}$ & $\begin{array}{l}\text { 1.DIAGNOdentlaser fluorescence } \\
\text { 2.Visual examination }\end{array}$ & $\begin{array}{l}\text { Results showed a strong relationship between examination } \\
\text { with the DIAGNOdent } \\
\text { and visual inspection. Diagnodent's sensitivity and specificity } \\
\text { were } 97 \% \text { and } 52 \% \text {, respectively }\end{array}$ & $\begin{array}{l}\text { DIAGNOdent is considered a reproducible and } \\
\text { accurate diagnostic tool that may be very helpful } \\
\text { in conjunction with a visual examination in the } \\
\text { detection of occlusal caries in permanent molars } \\
\text { in children }\end{array}$ \\
\hline $\begin{array}{l}\text { CH.Chu (2010) } \\
\text { (10) }\end{array}$ & $\begin{array}{l}\text { Occlusal surface for } \\
144 \text { Human 2nd } \\
\text { molars }\end{array}$ & $\begin{array}{l}\text { 1. DIAGNOdent (LF) } \\
\text { 2. Radiography (BW) } \\
\text { 3. Visual method } \\
\text { The gold standard is fissure } \\
\text { opening }\end{array}$ & $\begin{array}{l}\text { The sensitivity and specificity values were, respectively, } \\
0.89 \text { and } 0.44 \text { by visual detection, } 0.13 \text { and } 1.00 \text { by bitewing } \\
\text { radiography and } 0.70 \text { and } 0.84 \text { by DIAGNOdent. Caries detection } \\
\text { by a combination of visual examination and DIAGNOdent had } \\
\text { a sensitivity of } 0.67 \text { and specificity of } 0.94 \text {. ROC curve analysis } \\
\text { showed that this combined approach was superior to the other } \\
\text { methods }\end{array}$ & $\begin{array}{l}\text { Caries diagnosis made on the basis of a } \\
\text { combination of visual } \\
\text { method and DIAGNOdent showed a good level of } \\
\text { sensitivity and specificity and can be considered } \\
\text { an appropriate method for diagnosis of decayed } \\
\text { dentin. }\end{array}$ \\
\hline $\begin{array}{l}\text { A.Goel et al. } \\
\text { (2009) [11] }\end{array}$ & $\begin{array}{l}84 \text { primary molars } \\
\text { in } 52 \text { children (aged } \\
8-12 \text { years) which } \\
\text { were indicated for } \\
\text { extraction }\end{array}$ & $\begin{array}{l}\text { Diagnodent, visual and } \\
\text { tactile method and bitewing } \\
\text { radiographs for caries evaluation. } \\
\text { The gold standard was a } \\
\text { Histological examination of teeth } \\
\text { sections }\end{array}$ & $\begin{array}{l}\text { Enamel caries, values for sensitivity, specificity, and accuracy } \\
\text { for Diagnodent were } 85.19,50.00 \text {, and } 84.34 \% \text { according to } \\
\text { the manufacturer's cut-off limits. At dentin caries, the values of } \\
\text { sensitivity, specificity, and accuracy for Diagnodent were } 72.22 \text {, } \\
76.60 \text {, and } 74.70 \% \text { according to the manufacturer's cut-off } \\
\text { limits. }\end{array}$ & $\begin{array}{l}\text { Diagnodent showed higher sensitivity and } \\
\text { accuracy when compared with other conventional } \\
\text { methods for the detection of enamel caries, } \\
\text { whereas for the detection of dentinal caries, even } \\
\text { though the sensitivity was high, the accuracy of } \\
\text { the Diagnodent device was similar to other caries } \\
\text { diagnostic methods }\end{array}$ \\
\hline
\end{tabular}




\begin{tabular}{|c|c|c|c|c|}
\hline $\begin{array}{l}\text { Kavvadia K } \\
\text { (2008) [12] }\end{array}$ & $\begin{array}{l}\text { Oocclusal surface for } \\
50 \text { Human molars }\end{array}$ & $\begin{array}{l}\text { 1. Direct visual method (DV) } \\
\text { 2. Indirect visual method (IDV) } \\
\text { 3. Radiography BW } \\
\text { 4. DIAGNOdent (LF) } \\
\text { The gold standard is fissure } \\
\text { opening }\end{array}$ & $\begin{array}{l}\text { For enamel lesions, higher sensitivity was found with DV, while } \\
\text { higher specificity with the LF. For lesions into dentin, higher } \\
\text { sensitivity was found with the LF, while higher specificity with } \\
\text { the BWR. The device's accuracy was found to be } 0.61 \text { for enamel } \\
\text { lesions, while for lesions into dentin } 0.70 \text {, and its reliability was } \\
\text { excellent (ICC }=0.97 \text { ) }\end{array}$ & $\begin{array}{l}\text { Diagnodent is very reliable in the detection } \\
\text { of occlusal caries in deciduous teeth, and its } \\
\text { efficiency is similar to direct visual }\end{array}$ \\
\hline $\begin{array}{l}\text { Kuhnisch J } \\
\text { (2008) [14] }\end{array}$ & $\begin{array}{l}\text { The occlusal surface of } \\
311 \text { Human Molars }\end{array}$ & $\begin{array}{l}\text { 1. Visual method (ICDAS II) } \\
\text { 2. Visual method (WHO) } \\
\text { 3. DIAGNOdent (LF) }\end{array}$ & $\begin{array}{l}\text { The overall data suggested a relationship between higher ICDAS } \\
\text { II scores and higher DIAGNOdent values }\end{array}$ & $\begin{array}{l}\text { When ICDAS II criteria are used in vivo, it seemed } \\
\text { that LF didn't detect any finding. While it caused } \\
\text { more work and costs. Use of DIAGNOdent in a } \\
\text { field study in which visual criteria were applied } \\
\text { seemed to provide limited additional information }\end{array}$ \\
\hline $\begin{array}{l}\text { Costa AM (2008) } \\
{[14]}\end{array}$ & $\begin{array}{l}\text { Occlusal surfaces of } \\
199 \text { Human molars } \\
\text { and premolars }\end{array}$ & $\begin{array}{l}\text { 1. Diagnodent (LF) } \\
\text { 2. Radiography (BW) } \\
\text { 3.Visual method } \\
\text { The gold standard is opening of } \\
\text { caries }\end{array}$ & $\begin{array}{l}\text { It was found that the laser detection method showed high } \\
\text { scores of sensitivity }(0.93) \text { and specificity }(0.75) \text { and a moderate } \\
\text { positive predictive value }(0.63) \text {. Diagnodent had the lowest } \\
\text { value of the likelihood ratio }(3.68) \text {. }\end{array}$ & $\begin{array}{l}\text { It has been recommended to use laser in } \\
\text { combination with a visual method in order to } \\
\text { reduce the possibility of false-positive results. }\end{array}$ \\
\hline $\begin{array}{l}\text { Huth KC (2008) } \\
{[15]}\end{array}$ & $\begin{array}{l}\text { Occlusal surfaces of } \\
120 \text { Human } \\
\text { Molars }\end{array}$ & $\begin{array}{l}\text { 1. Diagnodent (Pen) } \\
\text { 2. Radiography (BW) } \\
\text { 3.Visual method } \\
\text { The gold standard is opening the } \\
\text { caries }\end{array}$ & $\begin{array}{l}\text { The intra-examiner reliabilities for the LFpen measurements of } \\
\text { the four operators were very good with intraclass correlations } \\
\text { (ICCs) between } 0.94 \text { and } 0.998 \text { at a high significance level }\end{array}$ & $\begin{array}{l}\text { It is possible to use Diagnodent as a complementary } \\
\text { device for occlusal surfaces caries }\end{array}$ \\
\hline $\begin{array}{l}\text { Anttonen V } \\
\text { (2004) [16] }\end{array}$ & $\begin{array}{l}\text { Occlusal surface for } \\
423 \text { Human } \\
\text { Permanent molars, } \\
315 \text { Human deciduous } \\
\text { molars }\end{array}$ & $\begin{array}{l}\text { Visual method and Diagnodent } \\
\text { (LF) for caries detection }\end{array}$ & $\begin{array}{l}\text { An increase in Diangodent values correlated positively with the } \\
\text { increase in visual score. The mean Diagnodent value at baseline } \\
\text { was significantly higher in teeth that became carious than in } \\
\text { those that remained sound during the follow-up }\end{array}$ & $\begin{array}{l}\text { Diagnodent, in combination with the visual } \\
\text { method, is a beneficial tool for dentists with less } \\
\text { experience for the diagnosis of caries in deciduous } \\
\text { and permanent molar teeth }\end{array}$ \\
\hline
\end{tabular}

Table 3: Selected studies about DIAGNOdent. 


\begin{tabular}{|c|c|c|c|c|}
\hline Author/Year & Subjects & Methodology & Results & Conclusion \\
\hline $\begin{array}{l}\text { Melek Tassoker } \\
\text { (2019) [17] }\end{array}$ & $\begin{array}{l}90 \text { third molar } \\
\text { teeth planned for } \\
\text { extraction }\end{array}$ & $\begin{array}{l}\text { 1, Visual inspection (ICDAS-II) } \\
\text { 2.laser fluorescence } \\
\text { (DIAGNOdent pen) } \\
\text { 3.(DIAGNOcam) } \\
\text { The gold standard is histo-logical } \\
\text { validation }\end{array}$ & $\begin{array}{l}\text { DIAGNOcam had the best correlation value }(0.616) \text { according to } \\
\text { histological observations and demonstrated a sensitivity rate of } \\
96.1 \% \text {, a specificity rate of } 61.5 \% \text {, and an accuracy rate of } \\
91.1 \%\end{array}$ & $\begin{array}{l}\text { Diagnocam was found to be the most effective } \\
\text { method for the diagnosis of occlusal caries with- } \\
\text { out cavitation in permanent molar teeth }\end{array}$ \\
\hline $\begin{array}{l}\text { Bhumireddy J.R. } \\
\text { (2018) [18] }\end{array}$ & $\begin{array}{l}249 \text { children' teeth } \\
\text { were examined at D1 } \\
\text { and D3 }\end{array}$ & $\begin{array}{l}\text { 1.International Caries De-tection } \\
\text { and Assessment System II (ICDAS } \\
\text { II) } \\
\text { 2. Digital bitewing radio-graphs }\end{array}$ & $\begin{array}{l}\text { Sensitivity at D1 for ICDAS II was } 95 \% \text {, and } 22.97 \% \text { for digital ra- } \\
\text { diographs. At D3, the threshold sensitivity of ICDAS II was } 94 . \% \text {, } \\
\text { whereas it was } 69 \% \text { for digital radiographs. }\end{array}$ & $\begin{array}{l}\text { ICDAS II showed better accuracy than digital } \\
\text { radiographs in detecting carious } \\
\text { lesions within the enamel, and both tools were } \\
\text { equally effective in the detection of dentinal cari- } \\
\text { ous lesions. }\end{array}$ \\
\hline $\begin{array}{l}\text { Kockanat A. } \\
\text { (2017) [19] }\end{array}$ & $\begin{array}{l}120 \text { primary molar } \\
\text { teeth }\end{array}$ & $\begin{array}{l}\text { 1.ICDAS II, 2.Radiographic } \\
\text { examination } \\
\text { 3.DIAGNOdent pen, } \\
\text { 4.CarieScan PRO 5.SoproLife } \\
\text { Camera } \\
\text { The gold standard is histo-logical } \\
\text { sectioning }\end{array}$ & $\begin{array}{l}\text { ICDAS and SoproLife camera showed the highest sensitivity } \\
\text { value at D1 and D3 thresholds in vivo, radiographic examination } \\
\text { showed the lowest sensitivity values }\end{array}$ & $\begin{array}{l}\text { The ICDAS II method could be sufficient alone in } \\
\text { the diagnosis of occlusal caries of primary teeth. } \\
\text { However, SoproLife camera may be useful in } \\
\text { monitoring caries lesions. }\end{array}$ \\
\hline $\begin{array}{l}\text { Goswami M. } \\
\text { (2015) [20] }\end{array}$ & 31 children & $\begin{array}{l}\text { 1. WHO criteria } \\
\text { 2. ICDASII } \\
\text { 3. DIAGNOdent }\end{array}$ & $\begin{array}{l}\text { The mean ICDAS-II values amounted to } 8.76 \pm 0.72 \text {. } \\
\text { The mean values for DMFS/def were } 7.67 \pm 0.91 \\
\text { whereas for DIAGNOdent it amounted to } 4.00 \pm 0.62\end{array}$ & $\begin{array}{l}\text { This study showed that the diagnostic capabili- } \\
\text { ties of the ICDAS-II criteria in comparison to the } \\
\text { traditional WHO criteria by means of the non- } \\
\text { cavitated caries lesions additionally detected. } \\
\text { The Diagnodent use in studies that already apply } \\
\text { detailed visual criteria seemed to add limited } \\
\text { additional information. }\end{array}$ \\
\hline
\end{tabular}

Table 4: Selected studies about ICDAS visual criteria. 


\begin{tabular}{|c|c|c|c|c|}
\hline Author/Year & Subjects & Methodology & Results & Conclusion \\
\hline Maria Melo (2017) [21] & $\begin{array}{l}\text { A total of } 302 \text { teeth (molars and pre- } \\
\text { molars) from } 152 \text { patients } 39.1 \pm 14.3 \\
\text { years old were studied }\end{array}$ & $\begin{array}{l}\text { DIAGNOdent and VistaProof) vs. } \\
\text { visual and tactile evaluation in the } \\
\text { diagnosis of occlusal caries in per- } \\
\text { manent teeth }\end{array}$ & $\begin{array}{l}\text { The sensitivity and specificity values of visual di- } \\
\text { agnosis were } 79 \text { and } 72 \% \text {, respectively, versus } 53 \\
\text { and } 98 \% \text { of tactile methods. Teeth with caries le- } \\
\text { sions showed significantly higher Diagnodent and } \\
\text { VistaProof scores than those caries-free. Using the } \\
\text { optimum cut-off point of } 23.5 \text {, Diagnodent, sen- } \\
\text { sitivity, and specificity values were } 92.4 \text { and } 92.7 \\
\% \text {, respectively, while it showed values of } 88.1 \text { and } \\
95.1 \% \text { with a cut-off point of } 28.5 \text {. The sensitivity } \\
\text { of the Vistaproof system varied between } 92.9 \% \\
\text { (cut-off point } 1.05 \text { ) and } 85.3 \% \text { (cut-off point } 1.3 \text { ), } \\
\text { with respective specificity values of } 95.8 \text { and } 88.6 \\
\% \text {. The areas under the curve were } 0.756,0.759 \text {, } \\
0.954 \text { and } 0.965 \text { for the visual and tactile methods } \\
\text { and for DIAGNOdent and VistaProof, respectively }\end{array}$ & $\begin{array}{l}\text { The fluorescence-based techniques } \\
\text { showed greater internal and exter- } \\
\text { nal validity than the visual and tactile } \\
\text { methods in diagnosing occlusal caries } \\
\text { in permanent teeth. VistaProof is the } \\
\text { best method for diagnosing caries in } \\
\text { its early stages. }\end{array}$ \\
\hline $\begin{array}{l}\text { Anahita Jablons- } \\
\text { ki-Momeni (2017) [22] }\end{array}$ & $\begin{array}{l}\text { One hundred ninety-three proximal } \\
\text { surfaces from } 18 \text { patients (average age } \\
\text { was } 29.5 \text { years (18.5-45.8 years) )were } \\
\text { examined visually using ICDAS and us- } \\
\text { ing digital radiographs for presence or } \\
\text { absence of enamel lesions }\end{array}$ & $\begin{array}{l}\text { Evaluate the performance of the Vis- } \\
\text { tacam iX NIR for the detection of ap- } \\
\text { proximal enamel lesions by compar- } \\
\text { ison of digital radiographic findings. }\end{array}$ & $\begin{array}{l}\text { A moderate correlation was found between all } \\
\text { detection methods. The agreement between the } \\
\text { radiographic and NIR findings was moderate for } \\
\text { the distinction between sound surfaces and enam- } \\
\text { el caries. Insignificant differences were found be- } \\
\text { tween the results }(P=0.07) \text {. }\end{array}$ & $\begin{array}{l}\text { Proxi head of the intraoral camera } \\
\text { VistaCam iX can provide findings } \\
\text { comparable to those of radiographs } \\
\text { for non-cavitated lesions. }\end{array}$ \\
\hline $\begin{array}{l}\text { Marta Mazur } \\
\text { (2020) [23] }\end{array}$ & $\begin{array}{l}\text { Occlusal surfaces of } 1011 \text { posterior } \\
\text { teeth in } 255 \text { patients aged } 13 \text { - } 20 \text { years } \\
\text { (mean age } 16 \pm 2.2 \text { years) }\end{array}$ & $\begin{array}{l}\text { compare the diagnostic outcomes of } \\
\text { subjective visual evaluation between } \\
\text { the International Caries Detection } \\
\text { and Assessment System (ICDAS-II) } \\
\text { and an intraoral fluorescence-based } \\
\text { camera (VistaCam iX Proof, Dürr } \\
\text { Dental, Bietigheim-Bissingen, Ger- } \\
\text { many) for the detection of pits and } \\
\text { fissures in early caries lesions of } \\
\text { posterior teeth }\end{array}$ & $\begin{array}{l}283(28 \%) \text { of the assessed teeth were ICDAS-II } \\
\text { code } 0 ; 334(33 \%) \text { code } 1 ; 189(18.7 \%) \text { code } 2 ; 176 \\
(17.4 \%) \text { code } 3 \text {; and } 29(2.9 \%) \text { code } 4 \text {. The agree- } \\
\text { ment between the two procedures was expressed } \\
\text { by using Cohen's and Fleiss' kappa statistics and } \\
\text { performing McNemar's test. VistaCam assessed in } \\
513(50.7 \%) \text { sound enamel; in } 292(28.9 \%) \text { initial } \\
\text { enamel decay; and in } 206(20.4 \%) \text { dentine caries. }\end{array}$ & $\begin{array}{l}\text { This comparative study showed a } \\
\text { poor agreement between the two di- } \\
\text { agnostic methods, especially between } \\
\text { ICDAS-II } 0,1 \text {, and } 2 \text { codes and fluores- } \\
\text { cence assessments. }\end{array}$ \\
\hline
\end{tabular}




\begin{tabular}{|c|c|c|c|c|}
\hline C.M. Moriyama 2014 & $\begin{array}{l}\text { Ten volunteers wore acrylic palatal ap- } \\
\text { pliances, each having six enamel blocks } \\
\text { demineralized for } 14 \text { days by immer- } \\
\text { sion into a } 20 \% \text { sucrose solu-tion, and } 3 \\
\text { of them were remineral-ized for seven } \\
\text { days using fluoride den-tifrice. } \\
\text { Sixty enamel blocks were evaluated at } \\
\text { baseline, after demineralization and } 30 \\
\text { blocks after remineralization by two ex- } \\
\text { aminers }\end{array}$ & $\begin{array}{l}\text { evaluate the effectiveness of fluo- } \\
\text { rescence-based methods (DIAGNO- } \\
\text { dent, LF; DIAGNOdent pen, LFpen, } \\
\text { and VistaProof fluorescence camera, } \\
\text { FC) in detecting demineralization } \\
\text { and remineralization on smooth } \\
\text { surfaces in situ } \\
\text { They were submitted to surface mi- } \\
\text { crohardness (SMH) and cross-sec- } \\
\text { tional microhardness analysis. The } \\
\text { integrated loss of surface hardness } \\
(\triangle \mathrm{KHN}) \text { was calculated }\end{array}$ & $\begin{array}{l}\text { The intraclass correlation coefficient for inter- } \\
\text { ex-aminer reproducibility ranged from } 0.21 \\
\text { (FC) to } 0.86 \text { (LFpen). SMH, LF, and LFpen values } \\
\text { pre-sented significant differences between the } \\
\text { three phases. However, FC fluorescence values } \\
\text { showed no significant differences between the } \\
\text { demineralization and remineralization phases. } \\
\text { Fluorescence values for baseline, demineralized } \\
\text { and remineralized enamel were, respectively, } 5.4 \pm \\
1.0,9.2 \pm 2.2 \text { and } 7.0 \pm 1.5 \text { for LF; } 10.5 \pm 2.0 \text {, } \\
15.0 \pm 3.2 \text { and } 12.5 \pm 2.9 \text { for LFpen, and } 1.0 \pm 0.0 \text {, } \\
1.0 \pm 0.1 \text { and } 1.0 \pm 0.1 \text { for FC. SMH and } \Delta \text { KHN } \\
\text { showed significant differences between deminer- } \\
\text { alization and remineralization phases. There was a } \\
\text { negative and significant correlation between SMH } \\
\text { and LF and LFpen in the reminer-alization phase }\end{array}$ & $\begin{array}{l}\text { LF and LFpen devices showed to be } \\
\text { effective in detecting demineraliza- } \\
\text { tion and remineralization on smooth } \\
\text { surfaces provoked in situ. }\end{array}$ \\
\hline $\begin{array}{l}\text { Anahita Jablons- } \\
\text { ki-Momeni } 2013 \text { [24] }\end{array}$ & $\begin{array}{l}306 \text { unrestored permanent teeth of } 26 \\
\text { patients }\end{array}$ & $\begin{array}{l}\text { Teeth were examined using (ICDAS) } \\
\text { criteria. Then, digital im-ages of } \\
\text { the surfaces were made using the } \\
\text { VistaProof cam. The ac-tual depth } \\
\text { of the lesions was as-sessed using } \\
\text { radiographs and/or clinically by } \\
\text { opening the lesion when appropri- } \\
\text { ate. Correlation between all meth- } \\
\text { ods was assessed using Spearman's } \\
\text { rank correlation coefficient (rs). } \\
\text { Sensitivity (SE) and specificity (SP) } \\
\text { were calculated at D1-(enamel le- } \\
\text { sions) and D3-(dentine caries) diag- } \\
\text { nostic threshold and area under the } \\
\text { ROC curve (AUC) were assessed }\end{array}$ & $\begin{array}{l}\text { A significant positive correlation was found be- } \\
\text { tween ICDAS, VP measurements, and the reference } \\
\text { standard ( } \mathrm{r} \mathrm{s} 0.46-0.71, \mathrm{p}<0.01 \text { ). SE and SP were } \\
\text { at the D1-diagnostic threshold level } 92.3 \text { and } 41.1 \\
\% \text {, respectively. At the D3-diagnostic threshold, SE } \\
\text { was } 25.9 \% \text { and SP } 97.9 \% \text {. The diagnostic perfor- } \\
\text { mance (AUC) was } 0.82 \text { (D1) and } 0.85 \text { (D3). Com- } \\
\text { bination of VP measurements with ICDAS showed } \\
\text { the SE value of } 74.1 \% \text { at D3-diagnostic threshold }\end{array}$ & $\begin{array}{l}\text { The VP showed good diagnostic per- } \\
\text { formance. } \\
\text { The combination of VP measure- } \\
\text { ments with ICDAS improved the SE in } \\
\text { detecting dentine lesions. }\end{array}$ \\
\hline
\end{tabular}




\begin{tabular}{|c|c|c|c|c|}
\hline María Melo 2015 [25] & $\begin{array}{l}\text { Thirty-two teeth (molars or premolars } \\
\text { of both arches scheduled for filling or } \\
\text { for use as posts in dental bridges) in } 28 \\
\text { patients. }\end{array}$ & $\begin{array}{l}\text { DIAGNOdentVistaProof and CarieS- } \\
\text { can } \\
\text { Fissurotomy was subsequently per- } \\
\text { formed for histological validation. }\end{array}$ & $\begin{array}{l}\text { Visual inspection showed an AUC-ROC of } 0.75 \text {, } \\
\text { with sensitivity and specificity values of } 0.75 \text {. } \\
\text { Tactile diagnosis showed AUC }=0.714 \text {, with max- } \\
\text { imum sensitivity (100\%) and a specificity value } \\
\text { of } 42.9 \% \text {. Diagnodent (cutoff point } 22.5 \text { )while Vi- } \\
\text { staProof (cutoff point } 1.1 \text { ) showed an AUC }=0.969 \text {, } \\
\text { while CarieScan (cutoff point } 21.5 \text { ) resulted in an } \\
\text { AUC }=0.973 \text {. These methods all had a sensitivity of } \\
\text { over } 92 \% \text {. The specificity of Diagnodent showed to } \\
\text { be maximum, while that of CarieScan and VistaP- } \\
\text { roof was } 75 \%\end{array}$ & $\begin{array}{l}\text { The new methods in the diagnosis of } \\
\text { caries (Diagnodent, VistaProof, and } \\
\text { CarieScan) showed similar results } \\
\text { and proved to be superior to the tra- } \\
\text { ditional visual and tactile methods. } \\
\text { Diagnodent was considered the most } \\
\text { effective technique, followed by Cari- } \\
\text { eScan and VistaProof }\end{array}$ \\
\hline $\begin{array}{l}\text { Anahita Jablons- } \\
\text { ki-Momeni } 2015 \text { [26] }\end{array}$ & $\begin{array}{l}\text { A total of } 419 \text { posterior teeth ( } 205 \text { pri- } \\
\text { mary molars, } 145 \text { permanent molars, } \\
\text { and } 69 \text { premolars) of } 35 \text { patients were } \\
\text { examined (average age: } 9.1 \text { years) }\end{array}$ & $\begin{array}{l}\text { Evaluated the capabilities of the Vi- } \\
\text { staProof (VP) fluorescence-based } \\
\text { camera for monitoring occlusal sur- } \\
\text { face caries. } \\
\text { The occlusal surfaces were clas- } \\
\text { si-fied visually according (ICDAS) } \\
\text { scores. } \\
\text { VP measurements were performed } \\
\text { at baseline and after six and twelve- } \\
\text { month. Correlation between meth- } \\
\text { ods was analyzed using Spearman's } \\
\text { rank correlation coeffi-cient. Wil- } \\
\text { coxon test was applied to monitor } \\
\text { whether VP identified changes as } \\
\text { well as ICDAS (a = 0.05). }\end{array}$ & $\begin{array}{l}\text { Correlations between ICDAS and VP were } \\
\text { significantly positive (rs: } 0.66-0.73, \mathrm{P}<0.001) \text {. } \\
\text { No significant differences were found between all } \\
\text { times for the ICDAS findings. Significant differenc- } \\
\text { es for the VP were ascertained for } \mathrm{t} 1 / \mathrm{t} 2(\mathrm{P}=0.03 \text { ). } \\
\text { Results based on cluster randomization showed } \\
\text { significant differences between ICDAS and VistaP- } \\
\text { roof concerning the absence/presence of changes } \\
\text { in the finding }(\mathrm{P}<0.0005) \text {. }\end{array}$ & $\begin{array}{l}\text { Correlation between ICDAS and VP } \\
\text { was strong. } \\
\text { The VP supported the findings of visu- } \\
\text { al examination for monitoring occlu- } \\
\text { sal sur-faces, although not all changes } \\
\text { could be detected with respect to the } \\
\text { visual find-ings. }\end{array}$ \\
\hline
\end{tabular}

Table 5: Selected studies about VistaCam/VistaProof. 


\begin{tabular}{|c|c|c|c|c|}
\hline Author/Year & Subjects & Methodology & Results & Conclusion \\
\hline M. Muller-Bolla 2017 & 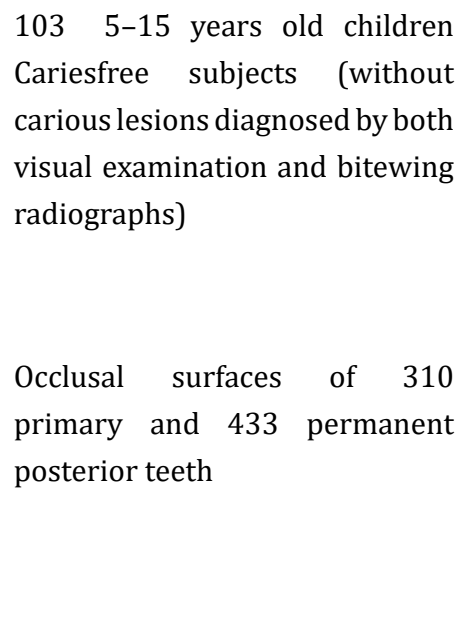 & $\begin{array}{l}\text { Soprolife vs. DIAGNOPen } \\
\text { The sensitivity, specificity, and area under } \\
\text { the Receiver Operating Characteristic } \\
\text { curve were evaluated using (ICDAS) and } \\
\text { radiographic examinations as the gold } \\
\text { standards. } \\
\text { The effectiveness of the Soprolife was } \\
\text { compared with Diagnopen on the same } \\
\text { teeth. } \\
\text { The reproducibility was assessed using } \\
\text { weighted a Kappa coefficient. }\end{array}$ & $\begin{array}{l}\text { All carious lesions using ICDAS } 1-6 \text { were } \\
\text { assessed, SE, SP, and AUC for the Soprolife } \\
\text { showed values of } 88.50,70.73 \text {, and } 0.84 \text {, } \\
\text { respectively. The validity was higher } \\
\text { for primary teeth (AUC }=0.90 \text { ) than for } \\
\text { permanent teeth }(0.80) \text {; the validity of } \\
\text { the Soprolife }(0.84) \text { was higher than that } \\
\text { of Diagnopen }(0.80) \text {. The inter- and intra- } \\
\text { examiner kappa coefficients scores were } \\
0.87 \text { and } 0.85 \text {, respectively. }\end{array}$ & $\begin{array}{l}\text { The Soprolife is considered a valid } \\
\text { instrument in providing reproducible } \\
\text { results, particularly for primary teeth. }\end{array}$ \\
\hline A. Kockanat 2017 [19] & $\begin{array}{l}\text { Children aged between } 9 \text { and } 12 \\
\text { years } \\
\text { One hundred twenty primary } \\
\text { molar teeth indication } \\
\text { for extraction confirmed } \\
\text { radiologically were included in } \\
\text { the present study. }\end{array}$ & $\begin{array}{l}\text { They compared ICDAS II, radiographic } \\
\text { examination, Diagnodent pen, CarieScan } \\
\text { PRO and SoproLife camera, and in vitro } \\
\text { using the mentioned diagnostic methods } \\
\text { except for radiographic examination. } \\
\text { In addition, in vitro examinations were } \\
\text { repeated two weeks later. } \\
\text { Sectioning and evaluation were done } \\
\text { using with Downer's histological criteria. } \\
\text { Sensitivity, specificity, positive and } \\
\text { negative predictive value, area under the } \\
\text { ROC curve were assessed at D1 and D3 } \\
\text { thresholds. The intra-and inter-examiner' } \\
\text { reproducibility were evaluated using } \\
\text { Cohen's kappa statistics and an intraclass } \\
\text { correlation coefficient }\end{array}$ & $\begin{array}{l}\text { Intra- and inter-examiner repeatability } \\
\text { were high for all tools } \\
\text { ICDAS and SoproLife camera had the highest } \\
\text { sensitivity value at D1 and D3 thresholds in } \\
\text { vivo, radiographic examination showed the } \\
\text { lowest sensitivity values. } \\
\text { ICDAS andSoproLife camera showed the } \\
\text { highest sensitivity values at D3 threshold } \\
\text { in vitro, CarieScan PRO showed the lowest } \\
\text { sensitivity value }\end{array}$ & $\begin{array}{l}\text { The ICDAS II method showed to be sufficient } \\
\text { alone in the diagnosis of occlusal caries } \\
\text { However, SoproLife camera tends to be } \\
\text { useful in monitoring caries lesions }\end{array}$ \\
\hline
\end{tabular}




\begin{tabular}{|c|c|c|c|c|}
\hline Elodie Terrer 2019 & $\begin{array}{l}\text { Six hundred twenty-eight } \\
\text { occlusal fissures were included } \\
\text { for analysis. } \\
\text { Participants ( }>\text { 18-year-old) were } \\
\text { chosen with apparent suspicious } \\
\text { occlusal fissures (based on visual } \\
\text { inspection); absence of occlusal } \\
\text { restorations and fissure sealants } \\
\text { (code 0, decision number 1, } \\
\text { ICDAS), }\end{array}$ & $\begin{array}{l}\text { Assessment of early caries detection } \\
\text { capabilities in enamel and dentine with } \\
\text { a laser-based system laser-based system } \\
\text { (DIAGNOdent }{ }^{\text {TM }} \text { pen) first and secondary } \\
\text { with a new fluorescence intra-oral camera } \\
\text { (Soprolife } \circledast \text { ).Visual inspection with a } \\
\text { loupe was used as control. }\end{array}$ & $\begin{array}{l}\text { the ROC curve showed higher values for the } \\
\text { Soprolife }{ }^{\circledR} \text { than for DIAGNOdent }{ }^{T M} \text { pen. } \\
\text { The values of the area under the curve } \\
\text { decreased from } 0.81 \text { (Soprolife } ® \text { in } \\
\text { daylight) to } 0.79 \text { (Soprolife } ® \text { in fluorescent } \\
\text { mode) and } 0.67 \text { for DIAGNOdent }{ }^{T M} \text { pen. } \\
\text { DIAGNOdent } t^{T M} \text { pen reproducibility (Intra } \\
\text { and inter investigator) showed a wide } \\
\text { dispersion, with many values scattered } \\
\text { beyond the confidence limits }( \pm 2 \mathrm{SD} \text { ), and } \\
\text { the weighted kappa coefficient, which was } \\
\text { quite low }(0.58)\end{array}$ & $\begin{array}{l}\text { Caries prevalence in terms of public health } \\
\text { policy is of interest, and caries detection } \\
\text { increased significantly when using a } \\
\text { fluorescence-based intra-oral camera. }\end{array}$ \\
\hline $\begin{array}{l}\text { Peter Rechmann } 2012 \\
\text { [27] }\end{array}$ & $\begin{array}{l}100 \text { subjects } \\
433 \text { posterior permanent } \\
\text { unrestored teeth were examined }\end{array}$ & $\begin{array}{l}\text { Assessed the diagnostic performance } \\
\text { of Diagnodent and two light-emitting } \\
\text { diode fluorescence tools: Spectra Caries } \\
\text { Detection Aid and Soprolife light- } \\
\text { induced fluorescence evaluator in both } \\
\text { daylight and blue fluorescence mode in } \\
\text { comparison to (ICDAS-II) in the detection } \\
\text { of caries lesions } \\
\text { On the occlusal surfaces,1066 data } \\
\text { points for each assessment method } \\
\text { were obtained for statistical evaluation, } \\
\text { including } 1034 \text { ICDAS scores. For the } \\
\text { Soprolife tool, a new scoring system was } \\
\text { applied. } \\
\text { For each assessment tool, each average } \\
\text { score for one given ICDAS code was } \\
\text { significantly different from each other } \\
\text { ICDAS code }\end{array}$ & $\begin{array}{l}\text { Normalized data linear regression } \\
\text { showed that Soprolife assessment tools } \\
\text { provided best caries score discrimination } \\
\text { followed by Diagnodent and Spectra Caries } \\
\text { Detection tool. } \\
\text { The area under the receiver operating } \\
\text { characteristics curve analysis showed the } \\
\text { same scores sequence when cut-off point } \\
\text { ICDAS codes } 0-1-2 \text { were grouped together. } \\
\text { Sensitivity and specificity values at the } \\
\text { same cut-off were obtained (Diagnodent } \\
87 / 66 \text {, Spectra Caries Detection Aid } \\
93 / 37 \text {, Soprolife 93/63, Soprolife blue } \\
\text { fluorescence } 95 / 55 \text {.) }\end{array}$ & $\begin{array}{l}\text { All fluorescence tools were able to } \\
\text { discriminate between distinct ICDAS II } \\
\text { scores. All tools shoed an AROC depicting the } \\
\text { overall capability to differentiate between } \\
\text { healthy and defective showed similar values } \\
\text { with the Soprolife tool in daylight as well as } \\
\text { blue fluorescence mode having the highest } \\
\text { values. } \\
\text { The linear regression fits for the caries } \\
\text { assessment toolsin relation to ICDAS II codes } \\
\text { showed that both SOPROLIFE assessment } \\
\text { tools with the highest slope values allow } \\
\text { for the better caries lesion discrimination } \\
\text { followed by Diagnodent. Spectra Caries } \\
\text { Detection Aid showed a relatively flat curve } \\
\text { with low discrimination ability } \\
\text { Those fluorescence tools, specifically those } \\
\text { with observational capabilities should aid } \\
\text { clinicians in applying more preventive and } \\
\text { minimally invasive treatment modalities } \\
\text { and will allow monitoring lesions for the } \\
\text { success of prevention measures over time }\end{array}$ \\
\hline
\end{tabular}




\begin{tabular}{|c|c|c|c|c|}
\hline $\begin{array}{l}\text { Mona Zeitouny } 2014 \\
\text { [3] }\end{array}$ & $\begin{array}{l}219 \text { permanent posterior teeth } \\
\text { from } 21 \text { subjects, with age } \\
\text { ranging from } 15 \text { to } 65 \text { years, } \\
\text { were examined }\end{array}$ & $\begin{array}{l}\text { Evaluation of a light-emitting diode } \\
\text { fluorescence tool, the Soprolife light- } \\
\text { induced fluorescence evaluator, and } \\
\text { compared it to the ICDAS-II in the } \\
\text { detection of occlusal caries. }\end{array}$ & $\begin{array}{l}\text { High reliability was found between } \\
\text { both methods (ICC }=0.92 \text {; IC }=0.901- \\
0.940 ; \quad P<0.001) \text {. Soprolife blue } \\
\text { fluorescence mode showed a high } \\
\text { sensitivity }(87 \%) \text { and a high specificity } \\
(99 \%)\end{array}$ & $\begin{array}{l}\text { Compared to the visual method } \\
\text { in the diagnosis of occlusal caries } \\
\text { lesions, it was found that Soprolife is a } \\
\text { reproducible and reliable tool. In terms } \\
\text { of categorizing noncarious lesions and } \\
\text { visual change in enamel, Soprolife shows } \\
\text { high sensitivity and specificity. It was } \\
\text { concluded that financially ICDAS is better. } \\
\text { Soprolife is easier for clinicians, and in } \\
\text { terms of efficiency, Soprolife was not better } \\
\text { than ICDAS but tended to be equivalent to } \\
\text { having the same advantages. }\end{array}$ \\
\hline $\begin{array}{l}\text { A. Theocharopoulou } \\
2015\end{array}$ & $\begin{array}{l}\text { Thirty-seven posterior } \\
\text { primary and permanent teeth } \\
\text { occlusal surfaces from } 20 \\
\text { children were examined }\end{array}$ & $\begin{array}{l}\text { Diagnodent pen and Soprolife } \\
\text { fluorescence intra-oral camera compared } \\
\text { to ICDAS. Cut-offs were made for all } \\
\text { methods to discriminate sound surfaces } \\
\text { and enamel caries from dentin caries. The } \\
\text { inter-examiner reliability was assessed } \\
\text { using intra-class correlation coefficient }\end{array}$ & $\begin{array}{l}\text { On white light images, the assessors found } \\
16 \text { enamel caries and } 21 \text { dentine caries } \\
\text { using the ICDAS system. On the Soprolife } \\
\text { fluorescent images, } 24 \text { enamel lesions, nine } \\
\text { dentine lesions, and four sound surfaces } \\
\text { were detected. The inter-examiner } \\
\text { reliability (ICC) of the ICDAS system on } \\
\text { white light images and of Soprolife on the } \\
\text { fluorescent images for average measures } \\
\text { was } 0.70 \text { and } 0.72 \text {, respectively. } \\
\text { The sensitivity and specificity values of } \\
\text { Soprolife ( } 95 \% C I) \text { were } 0.43 \text { and } 1.0 \text {, } \\
\text { respectively, using ICDAS as a reference } \\
\text { standard. while sensitivity and specificity } \\
\text { of Diagnodent ( } 95 \% C I) \text { was } 0.62 \text { and } 0.81 \\
\text { respectively }\end{array}$ & $\begin{array}{l}\text { A brief training of dentists in use the ICDAS } \\
\text { system showed satisfactory inter-examiner } \\
\text { reliability results } \\
\text { Soprolife and Diagnodent do not contribute } \\
\text { to better detection of early carious lesions }\end{array}$ \\
\hline
\end{tabular}

Table 6: Selected studies about Soprolife. 


\begin{tabular}{|c|c|c|c|c|c|c|c|c|}
\hline Study & $\begin{array}{l}\text { Sequence generation } \\
\text { (randomized) }\end{array}$ & $\begin{array}{c}\text { Sequence } \\
\text { concealment }\end{array}$ & $\begin{array}{c}\text { Blinded } \\
\text { participants } \\
\text { and } \\
\text { personnel }\end{array}$ & $\begin{array}{l}\text { Results analysis } \\
\text { blinded }\end{array}$ & $\begin{array}{c}\text { Participants loss } \\
\%\end{array}$ & $\begin{array}{l}\text { Reporting Bias } \\
\text { (reporting ll } \\
\text { outcomes) }\end{array}$ & $\begin{array}{l}\text { Other bias } \\
\text { (funding mn } \\
\text { companies) }\end{array}$ & Risk of Bias \\
\hline Castilho LS (2016) [9] & Unclear & Yes & Yes & Yes & $0 \%$ & No & No & Moderate \\
\hline CH. Chu (2010) [10] & Unclear & Yes & Yes & Yes & $0 \%$ & No & No & Moderate \\
\hline A.Goel et al. (2009) [11] & Unclear & yes & No & Yes & $0 \%$ & No & No & Moderate \\
\hline Kavvadia K (2008) [12] & $\begin{array}{l}\text { Distributed according to their } \\
\text { caries scoring }\end{array}$ & Yes & Yes & Yes & $0 \%$ & No & No & Low \\
\hline Kuhnisch J (2008) [13] & Unclear & Yes & Yes & Yes & $0 \%$ & No & No & Moderate \\
\hline Costa AM (2008) [14] & $\begin{array}{c}\text { Using indexes of sensitivity and } \\
\text { specificity of the diagnostic sys- } \\
\text { tems }\end{array}$ & Yes & Yes & Yes & $0 \%$ & No & No & Low \\
\hline Huth KC (2008) [15] & $\begin{array}{l}\text { One test tooth was chosen by } \\
\text { drawing } \\
\text { lots from a black box by an } \\
\text { independent assistant }\end{array}$ & Yes & Yes & Yes & $0 \%$ & Yes & Yes & Low \\
\hline Anttonen V (2004) [16] & $\begin{array}{l}\text { According to the difference in test } \\
\text { score registered at the two check- } \\
\text { ups }\end{array}$ & Yes & Yes & yes & $20 \%$ & No & No & Moderate \\
\hline Sahu RK (2020) [6] & $\begin{array}{l}\text { Samples were distributed as per } \\
\text { ICDAS coding }\end{array}$ & Yes & Yes & Yes & $0 \%$ & No & No & Low \\
\hline Maria Melo (2019) [7] & Unclear & Yes & Yes & Yes & $0 \%$ & No & No & Moderate \\
\hline $\begin{array}{l}\text { Basem M. Abuzenada } \\
\text { (2019) [8] }\end{array}$ & Unclear & Yes & Yes & Yes & $0 \%$ & No & No & Moderate \\
\hline
\end{tabular}

|||| https://doi.org/10.30654/MJD.10027 


\begin{tabular}{|c|c|c|c|c|c|c|c|c|}
\hline $\begin{array}{c}\text { Melek Tassoker (2019) } \\
{[17]}\end{array}$ & $\begin{array}{c}\text { The distribution of the samples } \\
\text { according to their histological } \\
\text { thresholds }\end{array}$ & Yes & No & Yes & $0 \%$ & No & No & Moderate \\
\hline $\begin{array}{l}\text { Bhumireddy J.R. (2018) } \\
\text { [18] }\end{array}$ & Unclear & Yes & Yes & Yes & $0 \%$ & No & No & Moderate \\
\hline Kockanat A. (2017) [19] & Unclear & Yes & Yes & Yes & $0 \%$ & No & No & Moderate \\
\hline Goswami M. (2015) [20] & Unclear & Yes & No & Yes & $0 \%$ & No & No & Moderate \\
\hline M. Muller-Bolla 2017 & Unclear & No & Yes & Yes & $0 \%$ & No & No & Low \\
\hline A. Kockanat 2017 [19] & Unclear & No & No & Yes & $0 \%$ & No & No & Moderate \\
\hline Elodie Terrer 2019 & Unclear & No & Yes & Yes & $0 \%$ & No & No & Low \\
\hline $\begin{array}{c}\text { Peter Rechmann } 2012 \\
{[27]}\end{array}$ & Unclear & Yes & Yes & Yes & $0 \%$ & No & Yes & Moderate \\
\hline $\begin{array}{c}\text { Mona Zeitouny } 2014 \\
{[3]}\end{array}$ & Unclear & Yes & Yes & Yes & $0 \%$ & No & No & Low \\
\hline A.Theocharopoulou 2015 & Unclear & Yes & Yes & Yes & $0 \%$ & No & No & Low \\
\hline Maria Melo 2017 [7] & Unclear & Yes & No & Yes & $0 \%$ & No & No & Low \\
\hline $\begin{array}{l}\text { Anahita Jablonski- } \\
\text { Momeni } 2017 \text { [22] }\end{array}$ & Yes & Yes & No & Yes & $0 \%$ & No & Yes & Moderate \\
\hline Marta Mazur 2020 [23] & Unclear & No & Yes & Yes & $0 \%$ & No & No & Low \\
\hline C.M. Moriyama 2014 & Unclear & No & No & Yes & $0 \%$ & No & No & Moderate \\
\hline $\begin{array}{l}\text { Anahita Jablonski- } \\
\text { Momeni } 2013 \text { [24] }\end{array}$ & Unclear & No & No & Yes & $0 \%$ & No & Yes & Moderate \\
\hline María Melo 2015 [7] & Unclear & No & No & Yes & $0 \%$ & No & No & Moderate \\
\hline $\begin{array}{l}\text { Anahita Jablonski- } \\
\text { Momeni } 2015\end{array}$ & Unclear & No & No & Yes & $1 \%$ & No & Yes & Moderate \\
\hline
\end{tabular}

Table 7: Risk of Bias analysis. 


\section{PRISMA 2009 flow diagram}
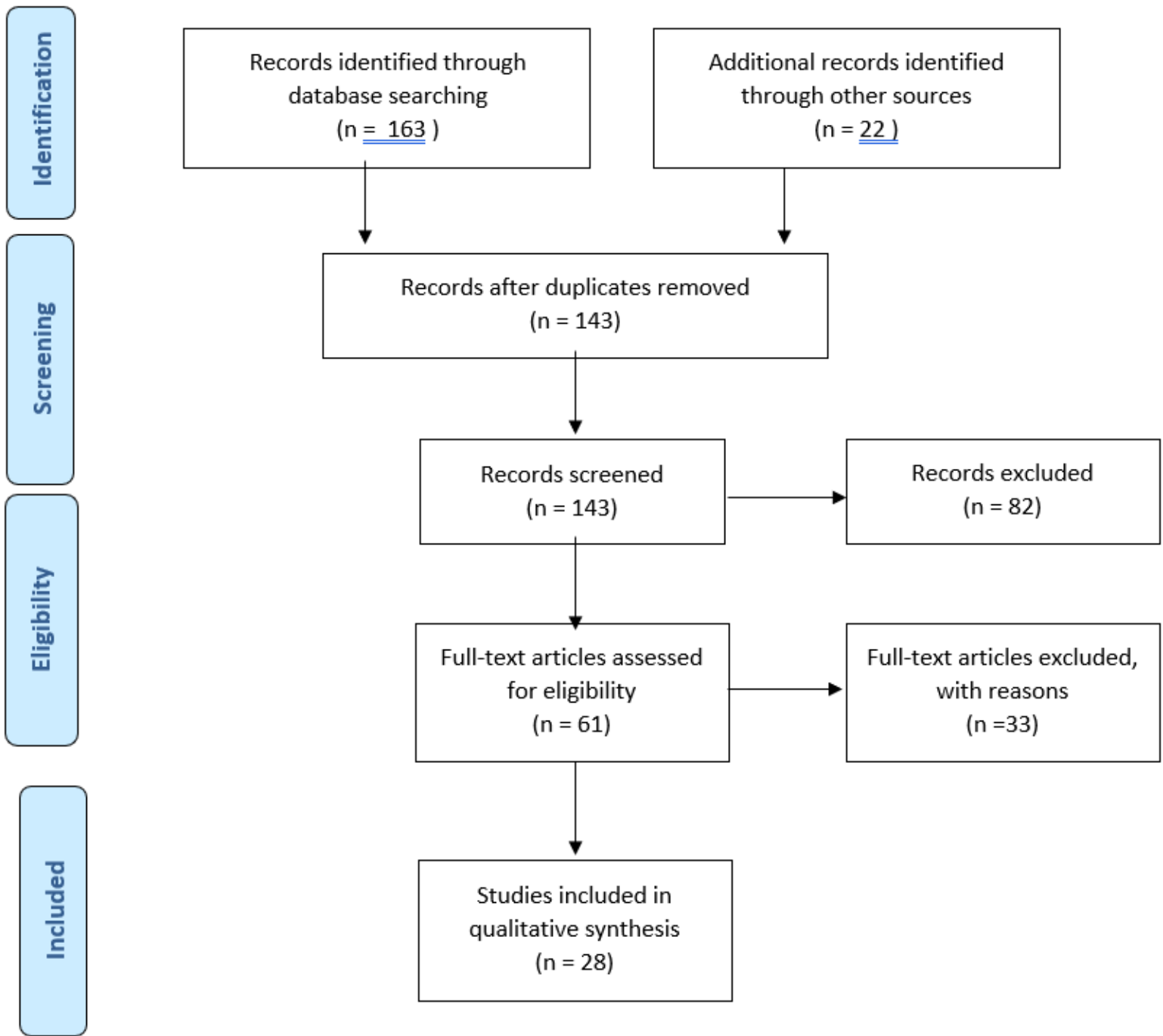

\section{DISCUSSION}

The current review was conducted to evaluate the in-vivo performance of digital dental radiography and some of the novel diagnostic tools in detecting initial carious lesions and microcavities on occlusal and proximal surfaces of both primary and permanent teeth in comparison to the visual and tactile inspection using the ICDAS diagnostic criteria.

Visual inspection has been the most frequently validated diagnostic technique for caries detection and using ICDAS diagnostic criteria proved good performance and accuracy in various in-vivo and in-vitro studies [28-33]. Accordingly, in our review visual inspection using ICDAS criteria was considered the comparator and gold standard protocol for detecting initial carious lesions.

Various studies assessed the digital radiography and recent diagnostic tools in detecting early carious lesions in-vivo and in-vitro, our review included recent in-vivo clinical trials as they are more relevant to the clinical diagnostic situations where the included studies assessed the diagnostic accuracy according to sensitivity, specificity, and receiver operating characteristic curves.

Previous systematic reviews related to our research's scope were identified a review by [34] was conducted to evaluate various diagnostic tools, the article included some old diagnostic technologies which became rarely available and missed some of the recent tools which proved promising performance, Also in 2016 [35] published a systematic review but it was directed to evaluate the diagnostic capabilities of Soprolife camera only. A more recent review [36] was evaluating various detection technologies but in relation to caries activity of cavitated and non-cavitated lesions, Also [37] carried out a systematic review and metaanalysis, but it was limited to the use of Diagnodent and Vistaproof camera for pre-cavitated lesions. 
According to previous reviews, none of them compared the widely available digital radiography and recent easily available and easy to use diagnostic tools side by side. Also, our review included clinical trial studies comparing other tools together and in comparison to the more commonly used visual and tactile methods following the ICDAS criteria on both occlusal and proximal surfaces of permanent or primary teeth.

The criteria of success and reliability of any caries detection tool depend on various factors; the tool should show high intrinsic and extrinsic validity with a high sensitivity values to limit as much as possible any false-negative test results to the test which means failing to detect active lesions; also it should have high specificity to avoid false-positive results referring to the presence of active lesion leading to unnecessary intervention [36]. The diagnostic accuracy of the discussed tools was also evaluated in relation to the Receiver Operating Characteristic (ROC) curves, which is a graphic presentation of the relation between true positive test results (sensitivity) and false positives ones (1-specificity). The area under the curve (AUC), allows proper assessment of the diagnostic performance of the tested tool and also allows determining the optimal cut-off point, which will discriminate between presence or absence of carious lesions [38].

Digital dental radiography proved to be a reliable tool in detecting initial carious lesions/ especially proximal lesions [7], also using filters as negative images allowed easier and more efficient detection of occlusal lesions [6]. The digital bitewing radiography was proposed to be high value and reliability in detecting proximal caries [8].

The studies published evaluating the Diagnodent device suggested that the device has high accuracy and reliability similar to or superior to visual and tactile methods [9]. The device was proved to be an efficient adjunct to other detection methods, especially in the case of non-experienced clinicians [16], but the limitation of its use was due to high cost and not providing valuable additional information [10].

ICDAS criteria for the diagnosis of dental caries were considered to be sufficient alone in detecting occlusal caries [19]. It was found that ICDAS II showed better performance accuracy than bitewing radiographs when the lesion is confined within enamel [18] but the use in conjunction with a recent diagnostic tool enhanced the outcomes $[17,20]$.

Regarding the included articles evaluating the Soprolife camera, there was a consistent agreement upon the accuracy of the device with sensitivity values ranging from $43 \%$ up to
$95 \%$ while specificity ranged from $55 \%$ to $99 \%$; generally, it was found that the Intra- and inter-examiner repeatability was high and the device is a valid and reliable tool which can increase the clinicians' capabilities to detect early carious lesions. These observations were correlated to the ability of Soprolife to accurately transmit blue fluorescent light through the enamel into dentin cores and reflected image shows red areas indicating bacteria and their byproducts [26] and its recommended to be used in conjunction to the ICDAS criteria which is considered more financially efficient and to enhance visual examination [3].

Studies related to VistaCam/VistaProof assessment it was found that in some articles VistaCam proved high accuracy in detecting early carious lesions $[21,24,25]$ with moderate to strong correlation in comparison to results obtained by visual and tactile methods ICDAS criteria [22,38]. Other studies found a low performance of VistaCam when compared to visual and tactile methods, and this result was justified by the need to modify the cut-off values of the device [39] moreover, poor correlation to visual and tactile diagnostic results were obtained in cases of ICDAS scores (0-2), and this result was due to the presence of saliva and blood which should be removed because they enhance the fluorescence and increases the scores obtained; also, removal of plaque from occlusal surfaces was required [23].

In agreement with previous reviews, the main aim of a recent diagnostic tool is to detect as early as possible the initial carious lesions to be able to apply a medical model rather than intervention. Generally, most of the recent diagnostic tools were found to be a very useful aid in diagnosing carious lesions and assessing their progress, the use of recent tools must be an addition to the standard visual and tactile protocol and not a replacement solely used tool to rely on completely.

\section{CONCLUSION}

The caries detection tools target the early detection of caries and prevent the progression of caries from demineralization to cavitation. None of the mentioned techniques were sufficient alone for the diagnosis of dental caries. In the future, with the advancements of the diagnostic tools, minimal changes in the tooth structure will be easily detected, and the dental structures will be protected by applying preventive treatments.

\section{AUTHOR CONTRIBUTIONS}

Shereen Hafez Ibrahim (associate professor of conservative dentistry): Corresponding author, project administration, 
supervision, conceptualization, validation, data curation, review.

Peter Edward: data extraction, methodology, resources, writing original draft

Reham Nabil: data extraction, methodology, resources, writing original draft

All authors have read and agreed to the published version.

\section{FUNDING}

Self-funded by the authors.

\section{CONFLICTS OF INTEREST}

The authors declare no conflict of interest.

\section{DATA AVAILABILITY STATEMENT}

The data presented in this study are available on request from the corresponding author.

\section{DISCLOSURE OF STATEMENT}

The authors declare that they have no conflicts of interest. This systematic review is not funded by any source.

\section{REFERENCES}

1. Pinheiro IV, Medeiros MC, Ferreira MÂ, Lima KC. (2004). Use of laser fluorescence (diagnodent ${ }^{\mathrm{TM}}$ ) for In vivo diagnosis of occlusal caries: A systematic review. J Appl Oral Sci. 12(3):177-81.

2. Yllmaz H, Keles Y. (2018). Recent Methods for Diagnosis of Dental Caries in Dentistry. Meandros Med Dent J. 19:1-8

3. Zeitouny M, Feghali M, Nasr A, Abou-Samra P, Saleh N, et al. (2014). SOPROLIFE system: an accurate diagnostic enhancer. Scientific World Journal. 2014:924741.

4. Chaza Kouchaji. (2012). Comparison between a laser fluorescence device and visual examination in the detection of occlusal caries in children. The Saudi Dental Journal. 24(3-4):169-174. https://doi.org/10.1016/j. sdentj.2012.07.002.

5. Marmaneu-Menero A, Iranzo-Cortés JE, Almerich-Torres T, Ortolá-Síscar JC, Montiel-Company JM, et al. (2020). Diagnostic Validity of Digital Imaging Fiber-Optic Transillumination (DIFOTI) and Near-Infrared Light Transillumination (NILT) for Caries in Dentine. J. Clin. Med. 9:420. https://doi.org/10.3390/jcm9020420.
6. Sahu RK. (2015). Assessment of diagnostic accuracy of a direct digital radiographic-CMOS image with four types of filtered images for the detection of occlusal caries. Journal of Indian Society of Pedodontics and Preventive Dentistry. 33(1).

7. Melo M. (2019). Combined Near-Infrared Light Transillumination and Direct Digital Radiography Increases Diagnostic In Approximal Caries. Scientific Reports. 9:14224.

8. Abuzenada BM. (2019). Detection of proximal caries with digital intraoral bitewing radiography: An interobserver analysis, Saudi Journal for Health Sciences. 8(1):38-41. https://www.saudijhealthsci.org/ text.asp?2019/8/1/38/256781

9. Castilho LS, Cotta FV, Bueno AC, Moreira AN, Ferreira $\mathrm{EF}$, et al. (2016). Validation of DIAGNOdent laser fluorescence and the International Caries Detection and Assessment System (ICDAS) in diagnosis of occlusal caries in permanent teeth: an in vivo study. Eur J Oral Sci; 124(2):188-194.

10. Chu CH, Lo ECM, You DSH. (2010). Clinical diagnosis of fissure caries with conventional and laser-induced fluorescence techniques. Lasers Med Sci. 25:355-362. https://doi.org/10.1007/s10103-009-0655-6

11. Goel A, Chawla HS, Gauba K, Goyal A. (2009). Comparison of validity of DIAGNOdent with conventional methods for detection of occlusal caries in primary molars using the histological gold standard: An in vivo study. J Indian Soc Pedod Prev Dent. 27(4):227-34.

12. Kavvadia K, Lagouvardos P. (2008). Clinical performance of a diode laser fluorescence device for the detection of occlusal caries in primary teeth. Int J Paediatr Dent. 18(3):197-204.

13. Kühnisch J, Berger S, Goddon I, Senkel H, Pitts N, et al. (2008). Occlusal caries detection in permanent molars according to WHO basic methods, ICDAS II and laser fluorescence measurements. Community Dent Oral Epidemiol. 36(6):475-484.

14. Costa AM. (2008). Use of Diagnodent for diagnosis of non-cavitated occlusal dentin caries. J Appl Oral Sci. 16(1):18-23. 
15. Huth KC. (2008). Clinical performance of a new laser fluorescence device for detection of occlusal caries lesions in permanent molars. Journal of dentistry. 36:1033-1040.

16. Anttonen V, Seppa L, Hausen H. (2004). A follow-up study of the use of DIAGNOdent for monitoring fissure caries in children. Community Dent Oral Epidemiol; 32(4):312-8. https://doi.org/10.1111/j.1600-0528.2004.00168.x.

17. Tassoker M, Ozcan S, Karabekiroglu S. (2020). Occlusal Caries Detection and Diagnosis Using Visual ICDAS Criteria, Laser Fluorescence Measurements, and NearInfrared Light Transillumination Images. Med Princ Pract. 29:25-31. doi: 10.1159/000501257.

18. Bhumireddy JR, Rmasubbareddy C, Srikanthkumar M, Sivakumar N. (2018). Comparison of International Caries Detection and Assessment System and Digital Radiographs for Detecting Occlusal Dental Caries: An In vivo Study. European Journal of General Dentistry. $\quad 7(3): 61-5 . \quad$ https://www.ejgd.org/text. asp?2018/7/3/61/241552

19. Kockanat A, Unal M. (2017). In vivo and in vitro comparison of ICDASII, DIAGNOdent pen, CarieScan PRO and SoproLife camera for occlusal caries detection in primary molar teeth. European Journal of Paediatric Dentistry. 18(2):99- 104.

20. Goswami M, Rajwar AS. (2015). Evaluation of cavitated and non-cavitated carious lesions using the WHO basic methods, ICDAS-II and laser fluorescence measurements. Journal of Indian Society of Pedodontics and Preventive Dentistry. 33(1):10-14. https://www.jisppd.com/text. asp?2015/33/1/10/148961

21. Melo M, Pascual A, Camps I, Del Campo A, Ata-Ali J. (2017). Caries diagnosis using light fluorescence devices in comparison with traditional visual and tactile evaluation: a prospective study in 152 patients Odontology. 105(3):283-290.

22. Jablonski-Momeni A, Jablonski B, Lippe N. (2017). Clinical performance of the near-infrared imaging system VistaCam iX Proxi for detection of approximal enamel lesions. BDJ Open. 3:17012.

23. Mazur M, Jedlinski M, Ndokaj A, Corridore D, Maruotti A, et al. (2020). Diagnostic Drama. Use of ICDAS II and Fluorescence-Based Intraoral Camera in Early Occlusal Caries Detection: A Clinical Study. Int J Environ Res Public Health. 17(8): 2937.
24. Jablonski-Momeni A, Liebegall F, Stoll R, HeinzelGutenbrunner M, Pieper K. (2013). Performance of a new fluorescence camera for detection of occlusal caries in vitro. Lasers in Medical Science. 28(1):101-109.

25. Melo M, Pascual A, Camps I, Del Campo A. (2015). In vivo study of different methods for diagnosing pit and fissure caries. J Clin Exp Dent. 7(3):e387-391.

26. Jablonski-Momeni A, Stachniss V, Ricketts DN, HeinzelGutenbrunner M, Pieper K. (2015). Reproducibility and accuracy of the ICDAS-II for detection of occlusal caries in vitro. Caries Res. 42(2):79-87.

27. Rechmann P, Rechmann B, Featherstone J, Charland D. (2012). Performance of laser fluorescence devices and visual examination for the detection of occlusal caries in permanent molars. Journal of Biomedical Optics. 17(3):036006.

28. Diniz MB, Rodrigues JA, Hug I, Cordeiro Rde C, Lussi A. (2009). Reproducibility and accuracy of the ICDASII for occlusal caries detection. Community Dent Oral Epidemiol. 37(5):399-404.

29. Lussi A, Megert B, Longbottom C, Reich E, Francescut P. (2001). Clinical performance of a laser fluorescence device for detection of occlusal caries lesions. European Journal of Oral Sciences. 109(1):14-19.

30. Lussi A, Megert B, Longbottom C, Reich E, Francescut P. (2001). Laser fluorescence may increase diagnostic sensitivity in detecting class I caries. Journal of EvidenceBased Dental Practice. 1(2):95-96.

31. Lussi A, Francescut P. (2003). Performance of conventional and new methods for the detection of occlusal caries in deciduous teeth. Caries Research. 37(1):2-7.

32. Lussi A, Hibst R, Paulus R. (2004). DIAGNOdent: an optical method for caries detection. J Dent Res. 83 Spec No C:C80-3.

33. Lussi A. Hellwig E. (2006). Performance of a new laser fluorescence device for the detection of occlusal caries in vitro. Journal of Dentistry. 34(7):467-471.

34. Pretty IA, Ekstrand KR. (2016). Detection and monitoring of early caries lesions: a review. Eur Arch Paediatr Dent. 17(1):13-25.

35. Domejean S, Rongier J, Muller-Bolla M. (2016). Detection of Occlusal Carious Lesion using the SoproLife((R)) Camera: A Systematic Review. J Contemp Dent Pract. 17(9):774-779. 
36. Drancourt N, Roger-Leroi V, Martignon S, JablonskiMomeni A, Pitts N, et al. (2019). Carious lesion activity assessment in clinical practice: a systematic review. Clinical Oral Investigations. 23(4):1513-1524.

37. Iranzo-Cortes JE, Montiel-Company JM, AlmerichTorres T, Bellot-Arcis C, Almerich-Silla JM. (2019). Use of DIAGNOdent and VistaProof in diagnostic of PreCavitated Caries Lesions-A Systematic Review and MetaAnalysis. J Clin Med. 9(1):p.20. https://doi.org/10.3390/ jem9010020.
38. Marczuk-Kolada G, Luczaj-Cepowicz E, Obidzinska M, Rozycki J. (2020). Performance of ICDAS II and fluorescence methods on detection of occlusal caries-An ex vivo study. Photodiagnosis Photodyn Ther. 29:101609.

39. Jablonski-Momeni A, Heinzel-Gutenbrunner M, Vill G. (2016). Use of a fluorescence-based camera for monitoring occlusal surfaces of primary and permanent teeth. Int J Paediatr Dent. 26(6):448-456. 